\title{
Evaluation of the attention capture and holding power of interpretive signs among visitors to a nature trail in the High Tatras National Park (Slovakia)
}

\author{
Juraj Švajda \\ Envigogika 12 (2) - Reviewed articles / Recenzované články
}

Published / Publikováno 28. 12. 2017

DOI: $10.14712 / 18023061.549$

\begin{abstract}
Nature trails have become very popular and have become the most widespread method of interpreting natural and cultural heritage. This paper presents the result of evaluation research of a nature trail in the High Tatras National Park (Slovakia). The holding power and attention capture of the individual panels were assessed by observation including further analysis of other factors related to the interpretive quality or location of the panels. Evaluation shows that the trail is overloaded with text and does not adequately link the communicated content with the surroundings. The individual trail panels have a relatively low degree of holding power and attention capture. The evaluation reveals the importance of good quality and thoughtful interpretation of natural heritage. Overall, the study also shows the difficulties associated with the use of statistical methods to analyze the effectiveness of selected trail features.
\end{abstract}

\section{Keywords}

Trail; evaluation; interpretation; holding power; attention capture

\section{Abstrakt}

Naučné stezky se staly populárním a široce rozšířeným prostředkem interpretace př́irodního a kulturního dědictví. Cílem prezentované př́padové studie je přispět ke zvýšení jejich kvality. Text předkládá výsledky evaluačního výzkumu naučné stezky $v$ Národním parku Vysoké Tatry (Slovensko). Na základě pozorování byly v rámci výzkumu vyhodnocovány atraktivita a síla jednotlivých panelů a provedeny související analýzy hodnotící význam dalších faktorů, jako je například umístění panelů. Evaluace ukázala, že naučná stezka je přesycená textem a dostatečně nepropojuje komunikovaný obsah se svým okolím. Jednotlivé panely vykazují relativně malou hladinu síly a atraktivity. Evaluace dále ukazuje na důležitost kvalitní a promyšlené interpretace prírodního dědictví. Celkově také studie poukazuje na problémy související s využitím statistických metod pro analýzu př́nosu vybraných rysů naučné stezky. Pro hlubší poznání problematiky pak navrhuje provedení dalších výzkumů, které by čerpaly ze zahraničních zkušeností při zohlednění interpretačních tradic čerpajících $\mathrm{z}$ jiného kontextu.

\section{Klíčová slova}

Naučná stezka; hodnocení; interpretace; síla; přitažlivost 


\section{Introduction}

Educational (nature, interpretive, self-guided) trails and information panels are among the most widespread means of interpreting natural and cultural heritage. They have advantages (e.g. simplicity and availability, 24 hours of operation) and disadvantages (little information, passive interaction) compared to other means (personal interpretation), and it is advisable to respect certain recommendations of the principles and practice of interpretation (Ham, 1992; Tilden, 2007). A particular issue is the methodology of interpretive evaluation for nature trails. Creation of interpretation trails usually starts with definition of means and subsequent search for goals, rather than vice versa. Interpretation plans that would rigorously define the need for a trail are only emerging in Slovakia; this case study could help to improve their quality. Several authors (Medek et al., 2016) correctly point to a misguided procedure for designing trails with interpretive panels. Rather than beginning with goals and then moving to resources, the process more typically begins with the "products" and then looking to find the goals, i.e., there are dozens of nature trails in natural sites, while the interpretation plans that define their purpose still not exist. There is still a great gap in implementing theory to practice of creating and evaluating nature trails: e.g. it is often an exception to the rule, setting the goal and target groups, identifying effects on the knowledge, attitudes or visitors' behavior. If information panels cannot attract visitors and reach them, they are more than just a lost opportunity: unjustified interference with the landscape, waste of funds, etc.

Educational trails and individual panels have been the subject of several evaluation studies. Interpretive quality is assessed by evaluators and is based on a set of simpler or more sophisticated qualitative criteria. The best-known example of an evaluation study of educational trails is the Master's and Carter's (1999) evaluation criteria, which are based on the principles of S. Ham's thematic interpretation (1992, 2013). The criteria are focused on evaluating the graphical layout of the panels, the use of language resources, the location of the panels, or the communication of a clear message for a given target group. Apart from interpretive quality, the evaluation study typically evaluates attention capture, which means the percentage of visitors who stopped at the panel compared to the total number of passersby as well as their holding power, i.e. the average percentage of time spent reading the panel compared to the total time needed (Davis, 2009; Carter, 2001; Ptáček et al, 2012).

The importance of the individual elements defining the interpretive quality of the panel is still under discussion. Several studies, for example, focused on the importance of subtitles of the panels, the size of the font or the location of the panel to attract the attention of visitors (Bitgood, 2000; Thompson \& Bitgood, 1988). Other studies compared the holding and attraction power of the panels, depending on their artistic and multi-purpose processing (Davis, 2009, Jensen, 2006, Crawford, 2007). Hall, Ham and Lackey (2010) investigated the effectiveness of various forms of communication regarding the conservation message. Attention capture of the panel is determined in most studies mainly by its appropriate location, a distinctive headline communicating a comprehensible idea, three-dimensional or otherwise graphically imaginative processing, and simple language with a reasonable level of text to communicate with the visitors.

The contribution of the interactivity of "experience trails", i.e. learning trails motivating visitors towards various activities, have been evaluated in some studies, e.g. in the Beňková and Činčera studies (2010) and in the evaluation study of the trail of Oldřichovské bučiny, published in Medek et al. (2016). Based on these studies, it seems that interactive objects are more likely to attract visitors' attention and keep it longer than panels that do 
not provide this interactivity. At the same time, it is not clear whether the higher attractiveness of the objects itself contributes to a higher degree of interpretive efficiency of the trail, i.e. its ability to communicate an intended message.

In spite of the incomplete results, it seems that the evidence to support a certain interpretive style is not too strong and that the attractiveness of the panels depends more on a number of factors (such as the suitability of the location and attractiveness of the site) than on the details. Studies exploring the holding power and attention capture of selected panels simultaneously highlighted the great differences existing within a single educational trail (Medek et al., 2016, p. 125). The question, therefore, arises as to whether such differences can be found within the nature trail in a relatively uniform way, i.e. the extent to which the factors that are not directly related to the processing of the panels themselves, but other factors, play a role. This question has become the subject of a study on the analysis of the holding power and attention capture of the individual panels of the nature trail "In the forest between the Lake and the lake" (in Slovak "Lesom medzi (Štrbským) Plesom (village) a (Popradským) plesom (lake)") in the High Tatras National Park in Slovakia.

\section{Methodology}

The presented study addresses the following evaluation questions:

- To what extent do the panels correspond to the criteria of Master and Carter?

- What are the attention capture and the holding power of the individual panels of the selected nature trail?

- $\quad$ Are there statistically significant differences in the attention capture and holding power of individual panels? If so, what factors can be attributed to?

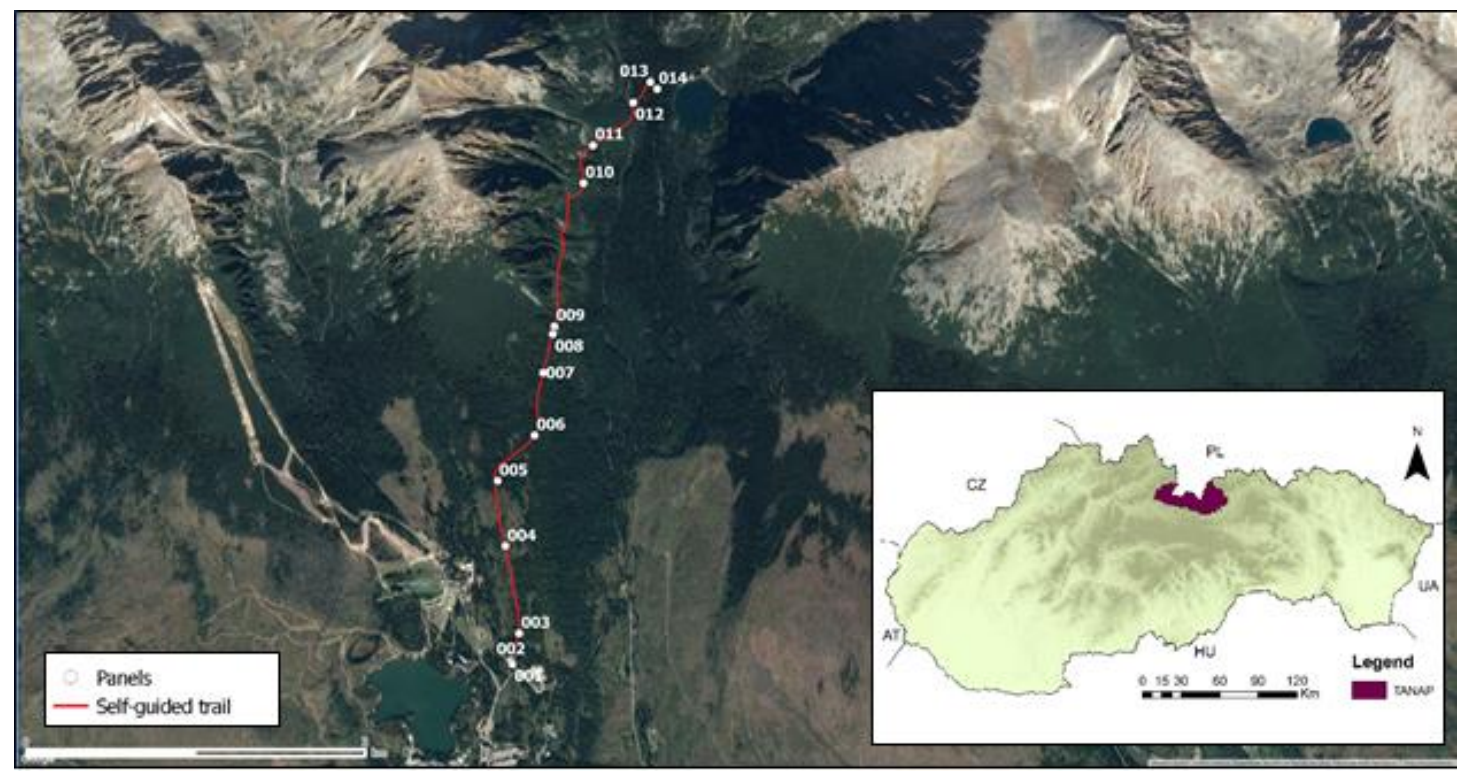

Fig. 1: Location of educational trail "In the forest between Lake and lake". The trail goes mainly through the forest between Štrbské Lake (village) and Popradské lake. 
The nature trail "In the forest between the Lake and the lake" was selected for research for practical reasons (esp. high visitation, good access and condition for observation of visitors). The trail goes mainly through the forest between Štrbské Lake (village) and Popradské lake and is five km long, leading through the back of Trigan (Figure 1). It has 14 stops, and it is possible to hike along it in 1.5 hours. The founder was State Forests of TANAP in 2001, and since then the trail has undergone reconstruction including extension. The texts of the panels are trilingual (SK-PL-EN), and in addition, each of the founders' and partners' logos, poems and quiz questions, can be found. The views of the individual trail panels and their location in the field are attached in the appendix of this article. Daily traffic on the trail during the summer season is about 2,000 visitors based on the regular counting of visitors. The dimensions of the panels are $120 \times 60 \mathrm{~cm}$, and they are made from metallic material covered with foil in a wooden frame.

The attention capture and holding power of the individual panels were assessed by the unobtrusive observation (indirect) method (Carter, 2001). From August 15th to August 18th, 2017, one of the authors watched the physical interaction of visitors with the panels (consistency guarantee) at hourly interval. Taking into account that panel no. 4 was totally missing, we evaluated a total of 13 panels. Each panel was observed for one hour within three days.

For further analysis, an index of the attention capture and holding power of each panel was determined. Attention capture index is the percentage of visitors who stopped at the panel compared to the total number of passers-by.

Holding power index is the average percentage of time (in seconds) which spent visitors by reading the panel compared to the total time needed for a complete understanding of the panel. The panel's evaluator - the author of the article - determined the necessary reading time by tracking the time required for reading (slow pace and only Slovak version while Slovak's and Czech's visitors represent the majority of tourists).

For the analysis of other factors related to the quality or placement of the panels, the following factors were also evaluated based on available literature (Masters \& Carter, 1999, Medek et al., 2016):

- Texts' characteristics, specifically the total number of sentences on the panel, the number of words on the panel, and the time required to read the text;

- Graphics and illustrations, specifically the number of panel images;

- Physical context, i.e. trail width in front of the panel, distance between panels, location of the panel in the landscape (on a scale of $0 / 1$, where 0 indicates location in forest and 1 location in open area) and panel damage rate (on a scale of $0 / 1$, where 0 indicates a damaged and 1 a completely undamaged and legible panel).

Interpretive quality of each panel was further evaluated by authors according to the Master and Carter methodology (1999). For the next analysis, the following variables were chosen as independent variables: encouragement, exploration, orientation, design, for which the 4-point scale (0-by no means to 3-to a large extent) was used. For other variables connection, message, availability, illustration - we used a 2-point scale (0-no, 1-yes). For analysis purposes, an index of interpretive quality, calculated as a sum of the points earnings in individual criteria by Master and Carter, was calculated for each panel. In total, it was possible to get 16 points. 
Due to the small size of the sample (13 panels), more precise statistical procedures, such as regression analysis, could not be used. The expected relationship between selected independent variables and dependent variables (holding power and attention capture of the panel) was therefore evaluated using the Pearson correlation test. The significance level was always determined as $a=0.05$.

The findings might have been further affected by a limited observation time, and the fact that the time needed for reading a text presented by the panels was assessed by one evaluator only. The results are to be taken as indicative and specific to this particular nature trail and cannot be generalized to other trails.

\section{Results}

In this chapter qualitative and quantitative assessment of evaluated trail is presented. First of all, the overall assessment of the interpretive quality for each individual trail panel is shown in Tab. 1. The "interpretive quality" variable, containing the aggregate point gain of the panels in all the evaluated criteria, has no statistically significant relationship with either the attention capture index $(r=0.36)$ or the panel holding power index $(r=-0.22)$.

Tab. 1: Interpretive quality index of trail panels calculated as a sum of the points earnings in individual criteria according Masters \& Carter, 1999 - encouragement, exploration, orientation and design rated on a scale of $0 / 3$ ( 0 indicates by no means and 3 to a large extent) + connection, message, availability and illustration rated on a scale of 0/1 (0-no, 1-yes).

\begin{tabular}{|c|c|c|c|c|c|c|c|c|c|}
\hline 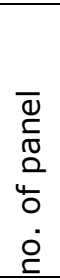 & 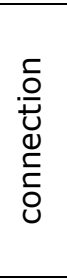 & 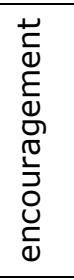 & 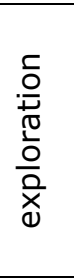 & 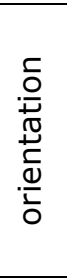 & 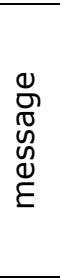 & 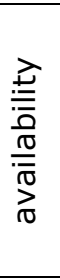 & 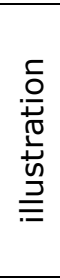 & $\begin{array}{l}\frac{5}{y} \\
\frac{d}{0}\end{array}$ & 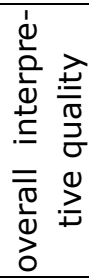 \\
\hline 1 & 1 & 0 & 1 & 2 & 1 & 1 & 0 & 1 & 8 \\
\hline 2 & 0 & 0 & 0 & 1 & 0 & 1 & 1 & 1 & 4 \\
\hline 3 & 0 & 0 & 1 & 1 & 1 & 1 & 1 & 2 & 7 \\
\hline 5 & 0 & 1 & 1 & 1 & 0 & 1 & 1 & 1 & 7 \\
\hline 6 & 1 & 0 & 0 & 1 & 1 & 0 & 1 & 1 & 6 \\
\hline 7 & 1 & 0 & 1 & 1 & 1 & 1 & 1 & 1 & 8 \\
\hline 8 & 1 & 0 & 1 & 2 & 1 & 1 & 1 & 1 & 10 \\
\hline 9 & 1 & 1 & 1 & 1 & 1 & 0 & 1 & 1 & 9 \\
\hline 10 & 1 & 0 & 1 & 1 & 1 & 0 & 1 & 2 & 8 \\
\hline 11 & 1 & 1 & 1 & 1 & 1 & 0 & 0 & 1 & 7 \\
\hline 12 & 1 & 0 & 1 & 2 & 1 & 0 & 0 & 1 & 7 \\
\hline 13 & 0 & 0 & 1 & 3 & 0 & 1 & 1 & 1 & 7 \\
\hline 14 & 0 & 0 & 0 & 2 & 0 & 1 & 0 & 1 & 4 \\
\hline
\end{tabular}

Generally speaking, despite the nature trail theme and its location in the forest environment, the content of the panels does not always relate to features in the surrounding area. This leads to a low degree of encouragement for the visitors to explore the surroundings. For example, panel no. 5 (see Figure 2) mentions soil horizons even though they are not available for observation except for the panel illustration. Panel no. 11 has the name 
"Forest and avalanches" but apart from the information about the avalanche accident, there is no connection with the forest.

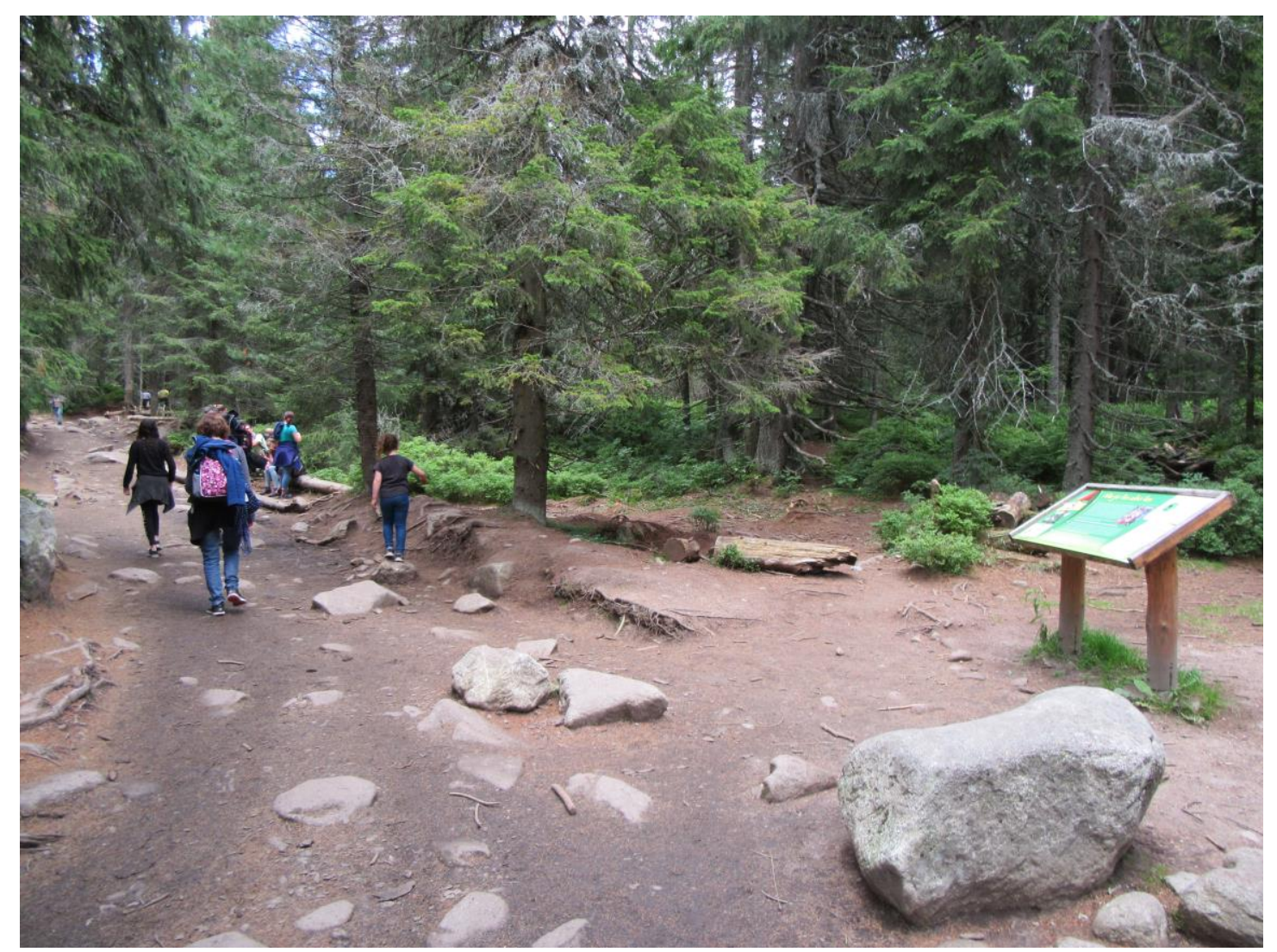

Fig. 2: Location of panel no. 5 "There is no forest like a forest"

It is possible to evaluate positively the quiz question addressed to a visitor at each panel, which may act as a stimulus, but is not always related to the content of the panel. For example, a rather complicated panel no. 2 (see Figure 3) explaining the distribution of living organisms of the ecosystem suddenly attracts the reader's attention to the dinosaur prints in the Tichá Valley. To enhance reader's emotional attachment, a snippet of a poem on each panel is used. In most cases, the panels are devoted to one topic; in terms of accessibility some panels have problems with legibility as the text is too small (panels no. 6 and no. 9). The use of illustrations to some extent increases the visitor's attention, but the overall design is outdated by today's standards.

Quantitative analysis of the panel text revealed (see Table 2) differences between individual panels. In particular, the difference in the minimum (149) and maximum (517) number of words on a panel is striking. However, based on statistical comparison there was no relationship between the number of words and affect either the attention capture or the holding power of the panel (see Table 3). 


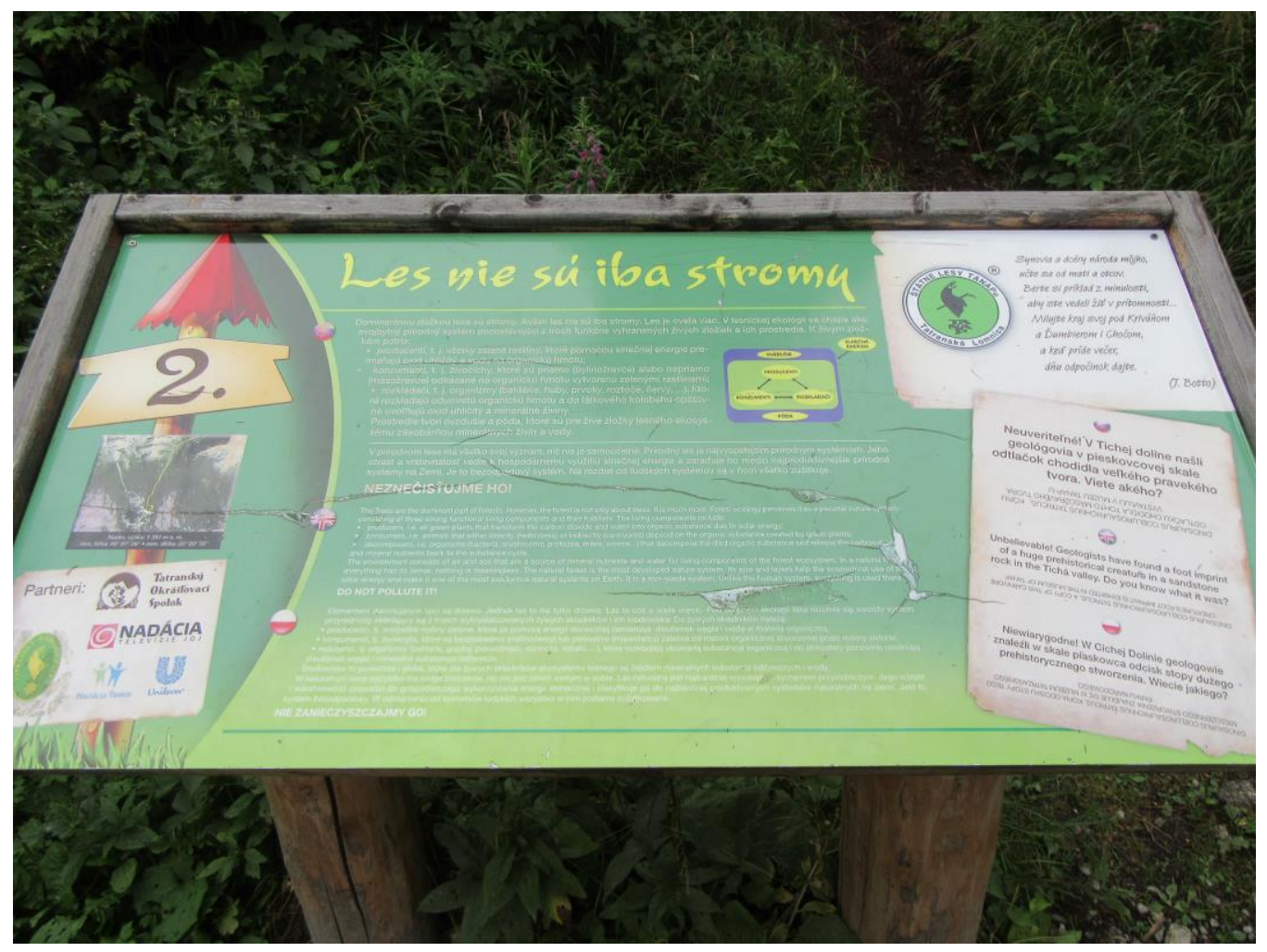

Fig. 3: Graphical design of panel no. 2 "The forest is not just trees"

Tab. 2: Text and graphic evaluation of individual trail panels based on texts' characteristics and illustrations, the time required for reading was determined by the panel's evaluator the author of the article - by tracking.

\begin{tabular}{|c|c|c|c|c|c|c|}
\hline no. of panel & name (topic) of panel & 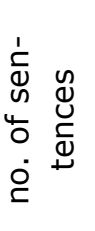 & $\begin{array}{l}0 \\
0 \\
0 \\
0 \\
3 \\
0 \\
0 \\
0\end{array}$ & 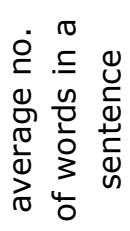 & 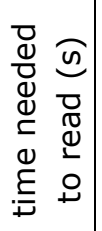 & 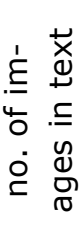 \\
\hline 1 & The forest speaks & 13 & 149 & 11 & 65 & 1 \\
\hline 2 & The forest is not just trees & 20 & 240 & 12 & 95 & 1 \\
\hline 3 & $\begin{array}{l}\text { The forest originated over thousands of } \\
\text { years }\end{array}$ & 17 & 237 & 14 & 98 & 1 \\
\hline 5 & There is no forest like a forest & 21 & 233 & 11 & 82 & 1 \\
\hline 6 & About forest animals & 83 & 517 & 6 & 154 & 15 \\
\hline 7 & About forest trees & 23 & 244 & 11 & 89 & 1 \\
\hline 8 & Swiss pine & 20 & 211 & 10 & 75 & 1 \\
\hline 9 & About forest plants & 67 & 495 & 7 & 143 & 15 \\
\hline 10 & Even the forest ends somewhere & 18 & 198 & 11 & 62 & 2 \\
\hline 11 & Forest and avalanches & 12 & 161 & 13 & 38 & 2 \\
\hline 12 & Forest and water & 18 & 201 & 11 & 58 & 1 \\
\hline 13 & Don't hurt the forest & 21 & 261 & 12 & 78 & 2 \\
\hline 14 & Conclusion & 7 & 94 & 13 & 26 & 1 \\
\hline
\end{tabular}


Tab. 3: Attention capture and holding power of individual trail panels - attention capture index is the percentage of visitors who stopped at the panel compared to the total number of passers-by, holding power index is the average percentage of time (in seconds) which spent visitors by reading the panel compared to the total time needed for a complete understanding of the panel.

\begin{tabular}{|l|c|c|c|c|}
\hline no. of panel & $\begin{array}{c}\text { total number of } \\
\text { passing visitors }\end{array}$ & $\begin{array}{c}\text { number of visitors who } \\
\text { stopped at the panel }\end{array}$ & $\begin{array}{c}\text { attention } \\
\text { capture (\%) }\end{array}$ & $\begin{array}{c}\text { holding } \\
\text { power (\%) }\end{array}$ \\
\hline 1 & 415 & 52 & 12.5 & 12.6 \\
\hline 2 & 553 & 48 & 8.6 & 23.1 \\
\hline 3 & 417 & 66 & 15.8 & 17.1 \\
\hline 5 & 283 & 45 & 15.9 & 38.6 \\
\hline 6 & 248 & 35 & 14.1 & 20.8 \\
\hline 7 & 313 & 63 & 20.1 & 17.6 \\
\hline 8 & 309 & 61 & 19.7 & 14.6 \\
\hline 9 & 304 & 72 & 23.7 & 20.3 \\
\hline 10 & 140 & 38 & 27.1 & 10.7 \\
\hline 11 & 213 & 64 & 30 & 6 \\
\hline 12 & 316 & 37 & 11.7 & 8.4 \\
\hline 13 & 283 & 105 & 37.1 & 5.6 \\
\hline 14 & 314 & 65 & 20.7 & 13.4 \\
\hline
\end{tabular}

Most investigated relationships (number of words, number of pictures, the distance between panels in relation to attention capture and holding power) were not statistically significant. The holding power of the panels positively correlated with the trail width in front of the panel $(r=0.55)$. Neither the attention capture of the panels nor the holding power of the panels were influenced by whether the panel was placed on the site with a view of the landscape (holding power $z=1.24, p=0.21$, attention capture $z=-0.95, p=0.34$ ) or if it is in good condition (holding power $z=1.78, p=0.07$, attention capture $z=-0.5, p=0.61$ ). 
Tab. 4: Location and physical condition of trail panels - trails width and distance between panels were measured in the field, view from panel to landscape was rated on a scale of $0 / 1$, where 0 indicates location in forest and 1 location in open area, condition of panel as damage rate was evaluated on a scale of $0 / 1$, where 0 indicates a damaged and 1 a completely undamaged and legible panel.

\begin{tabular}{|l|c|c|c|c|}
\hline no. of table & $\begin{array}{c}\text { trail width in front of } \\
\text { the panel }(\mathrm{cm})\end{array}$ & $\begin{array}{c}\text { distance between } \\
\text { panels }(\mathrm{m})\end{array}$ & $\begin{array}{c}\text { view from panel } \\
\text { to landscape }\end{array}$ & $\begin{array}{c}\text { condition of } \\
\text { panel }\end{array}$ \\
\hline 1 & 200 & 0 & 0 & 1 \\
\hline 2 & 300 & 41 & 0 & 0 \\
\hline 3 & 150 & 253 & 0 & 0 \\
\hline 5 & 400 & 1389 & 0 & 1 \\
\hline 6 & 300 & 575 & 0 & 1 \\
\hline 7 & 150 & 572 & 0 & 1 \\
\hline 8 & 150 & 361 & 1 & 1 \\
\hline 9 & 150 & 79 & 1 & 1 \\
\hline 10 & 150 & 1409 & 1 & 0 \\
\hline 11 & 200 & 394 & 1 & 0 \\
\hline 12 & 150 & 556 & 1 & 0 \\
\hline 13 & 200 & 252 & 0 & 0 \\
\hline 14 & 400 & 95 & 0 & 0 \\
\hline
\end{tabular}

\section{Discussion}

From the evaluation results, weaknesses can be seen in the interpretive quality of the nature trail. These are particularly apparent from the analysis of the communicated text. The panels are relatively unbalanced (e.g. a number of words and sentences) despite the uniformity of the text, but overall there is too much text for the size of panels. According to Ham (1992), panels should not contain more than 225 words in a maximum of 15 sentences. These criteria are met by only three out of the 13 evaluated panels.

Another obvious deficiency is the lack of connection between the panels and their surroundings, resulting in insufficient encouragement for visitors to actively explore these surroundings.

Poor design of the panels may cause relatively low attention capture and holding power of the panels. The typical level of attention capture for interpretive panels is $30-40 \%$, the reading time of the panel is approximately 20-40 seconds, and the holding power is about 50\% (Ptáček et al., 2012). However, these numbers can be disputed as they are not research-based. These levels do not match any of the panels, though two showed a higher degree of attention capture than the above-mentioned level. One reason may also be the fact that for many visitors the area of the Popradské lake is not a final hiking destination but rather a starting point for longer hikes (Rysy or Kôprovský peak, etc.). It could be assumed also that the day and time of the day might influence the audience in both quantitative and qualitative way. Another issue could be connected with a wide range of reading speeds, the nationality of visitors i.e. language issue etc. 
Statistically insignificant levels of correlation between variables characterizing nature trail features and the attention capture and the holding power of individual panels are likely to be attributable to the very small sample. Another explanation may be that the differences in the quality of individual panels were not so large as to be reflected in the statistical analysis. From this perspective, the statistically significant relationship between the width of the trail and the strength of the board is interesting, as this could indicate that this factor plays a role in the readers' readiness to read the whole panel.

Surprisingly, there is also not fully researched the connection between the placement of the panel and its attractiveness, which was documented in the study of Hall et al. (Hall, Ham and Lackey, 2010). It is possible that the results are again influenced by the small sample size.

Overall, the study shows the difficulties associated with the use of statistical methods to analyze the effectiveness of selected trail features. It seems that any further research will have to be based on data from a number of educational trails so that the total number of scanned panels enables data processing by adequate statistical methods.

A relatively easy solution for evaluating nature trails is to compare the level of attention capture and the holding power of panel with a predetermined desirable level. However, there is a question about the basis on which such levels can be determined. In the studies published by Medek et al. (2016), the attention capture of panels on various nature trails ranges in a wide range from one to seventy percent. Neither do Ptáček et al. (2012) indicate in their publication how they came to the "usual level", and it is natural to assume that any experience from abroad will be influenced by other contexts and interpretive traditions. Therefore, it is not clear whether it is purely arbitrary to set a "desirable" level, to what extent it is possible to rely on foreign literature or whether it is appropriate to try to make use of existing, regionally relevant research of other educational trails. We cannot rule out either possibility of changing attention capture and holding power over time.

Any further research should, in addition to the properties of the panels, also focus on other parameters related to visitors, their demographic characteristics (age, gender, groups of children, etc.), motivation to visit and their interaction with the tables (Falk, Heimlich, \& Foutz, 2009; Gyllenhaal et al., 2012). Similarly, in Central Europe conditions, the impact of different ways of influence on the behavior of visitors (Cialdini et al., 2006), as well as the use of, for example, Fry's Readability Test (Masters \& Carter, 1999) should be investigated.

\section{Conclusion}

The study presents the results of the evaluation study of the nature trail "In the forest between the Lake and the lake". The evaluation shows that the educational trail is overloaded with text and does not adequately link the content communicated with its surroundings. The individual trail panels have a relatively low value of attention capture and holding power. The experience with the evaluation reveals the importance of a good quality and thoughtful interpretation of the natural heritage, as well as the difficulties associated with its evaluation.

\section{Acknowledgement}

The authors would like to thank Veronika Lacušová for her help during the data collection in the field and Martina Škodová for map production. Anonymous reviewers and editors provided many helpful suggestions for substantial improvements of the manuscript. 


\section{References}

- Beňková, V., \& činčera, J. (2010). Prožitkové naučné stezky jako prostředek environmentální interpretace krajiny. (Experiential learning trails as a means for environmental interpretation. In Czech) Envigogika: Charles University E-journal for Environmental Education, 5(2), Retrieved from http://www.envigogika.cuni.cz/index.php/Envigogika/article/view/51 http://dx.doi.org/10.14712/18023061.51

- Bitgood, S. (2000). The Role of Attention in Designing Effective Interpretive labels. Journal of Interpretation Research, 5(2), 31-45.

- Crawford, J. (2007). Kea Exhibits : The Dynamics of Kea Behaviour and Interpretive Signage on Visitor Interest. : Unitec Institute of Technology.

- Carter, J. (2001). A sense of place - an interpretive planning handbook. Tourism and the environment initiative. Inverness.

- Cialdini, R. B., Demaine, L. J., Sagarin, B. J., Barrett, D. W., Rhoads, K., \& Winter, P. L. (2006). Managing social norms for persuasive impact. Social Influence, 1(1), 3-15. Retrieved from http://www.tandfonline.com/doi/abs/10.1080/15534510500181459 http://dx.doi.org/10.1080/15534510500181459

- Davis, S. (2009). Interpretive Sign Use Within The City of Fort Collins Natural Areas. A Focus on Repeat Visitors. Retrieved from: http://www.fcgov.com/naturalareas/pdf/interp-sign-eval.pdf?1256847838.

- Falk, J. H., Heimlich, J. E., \& Foutz, S. (2009). Free-choice learning and the Environment. Lanham: Altamira Press.

- Gyllenhaal, E. D., Perry, D. L., \& White, D. (2012). Summative evaluation of the Trail of time at Grand Canyon. Albuquerque: University of New Mexico.

- Hall, T. E., Ham, S. H., \& Lackey, B. K. (2010). Comparative evaluation of the attention capture and holding power of novel signs aimed at park visitors. Journal of interpretation research, 15(1), 15-38.

- Ham, S. H. (1992). Environmental Interpretation: A practical guide for people with big ideas and small budgets. Colorado: Fulcrum Publishing.

- Ham, S. H. (2013). Interpretation - making a difference on purpose. Golden: Fulcrum Publishing.

- Jensen, K. A. (2006). Effects of the Artistic Design of Interpretive Signage on Attracting Power, Holding Time and Memory Recall. A Thesis. : Faculty of Humboldt State University. Retrieved from http://scholarworks.calstate.edu/bitstream/handle/2148/141/Jensen Thesis.pdf?sequence $=1$

- Masters, D. \& Carter, J., (1999). What have we got and is it any good? A practical guide on how to survey and assess heritage interpretation. Highland interpretative strategic project.. .

- Medek, M., Činčera, J., Gregorová, J., Pořízová, K., \& Lisková, M. (2016). Náučné stezky: Zpracování a hodnocení nepřímých interpretačných programů. (Educational 
paths: processing and evaluating indirect interpreting programs. In Czech.). Brno: Masarykova univerzita.

- Ptáček, L., Růžička, T., Medek, M., Hušková, B., \& Banaš, M. (2012). Jak pre(d)kládat svět. (How to translate or present the world.) In Czech. Brno: Nadace Partnerství.

- Thompson, D., \& Bitgood, S. (1988). The Effects of Sign Length, Letter Size, and Proximity on Readings. Visitor Studies: Theory, Research, and Practice, 101(112), 10-1080. Retrieved from http://www.tandfonline.com/doi/full/10.1080/10645578809445744 http://dx.doi.org/10.1080/10645578809445744

- Tilden, F. (2007). Interpreting our Heritage. Chapell Hill: The University of. Chapel Hill: North Carolina Press. 


\section{Appendix}
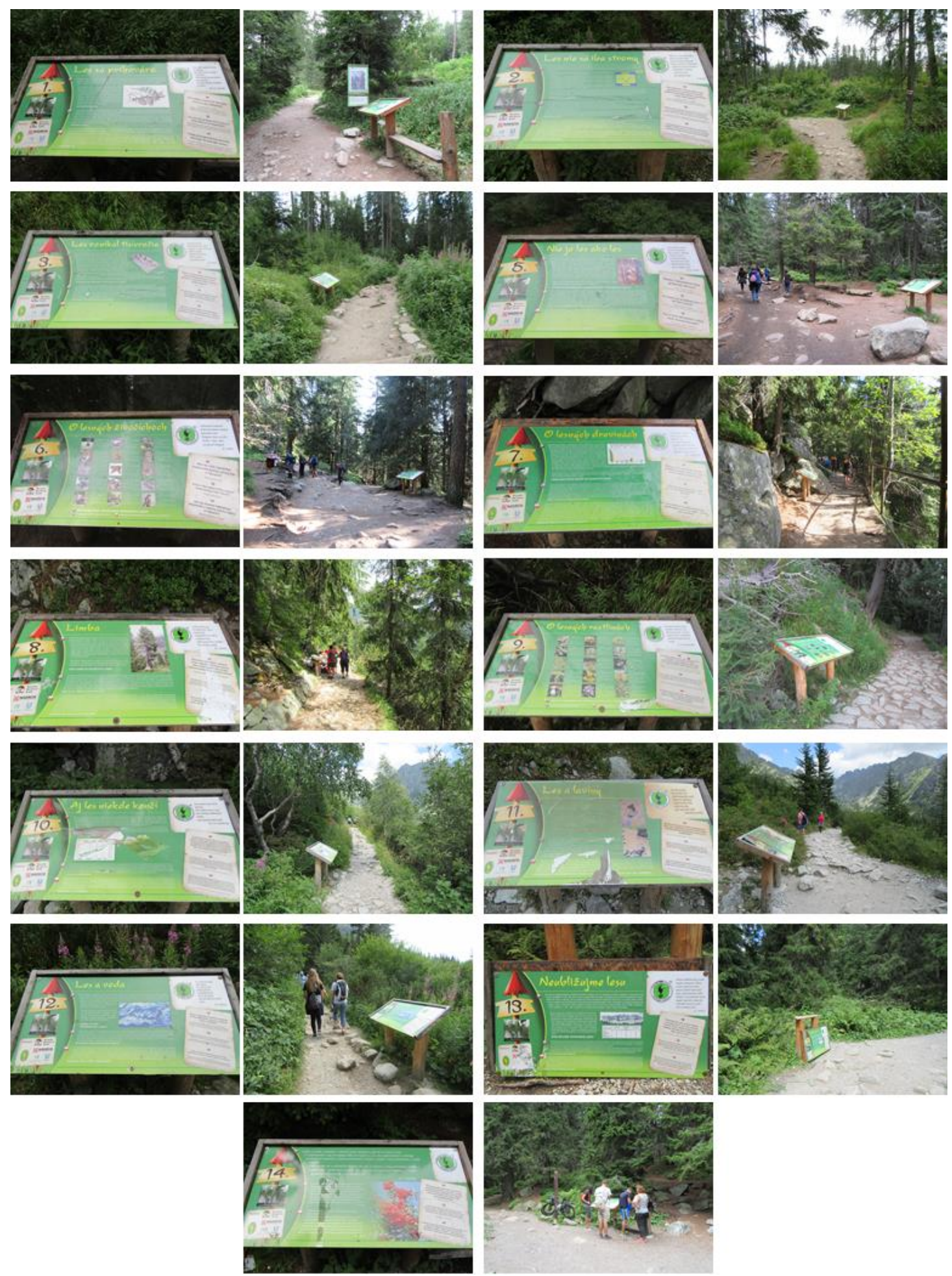
The design of the individual trail panels (e.g. 1a) and their location in the field (e.g. 1b).

\begin{tabular}{|l|l|l|l|}
\hline $1 a$ & $1 b$ & $2 a$ & $2 b$ \\
\hline $3 a$ & $3 b$ & $5 a$ & $5 b$ \\
\hline $6 a$ & $6 b$ & $7 a$ & $7 b$ \\
\hline $8 a$ & $8 b$ & $9 a$ & $9 b$ \\
\hline $10 a$ & $10 b$ & $11 a$ & $11 b$ \\
\hline $12 a$ & $12 b$ & $13 a$ & $13 b$ \\
\hline & $14 a$ & $14 b$ & \\
\hline
\end{tabular}

